\title{
Output-driven EAP Teaching for Chinese College Students Based on Blended Learning
}

\author{
Xian Tang \\ School of Foreign Languages \\ Wuhan Textile University \\ Wuhan, China \\ txianne@163.com
}

\begin{abstract}
This paper intends to discuss how to make EAP teaching design in an output-driven approach based on blended learning. It firstly made a literature review about the research on EAP both in China and abroad, and then proposed the possible EAP course arrangement according to students' current learning situation. Then it summarized the main points of output-driven approach and proposed the possible teaching methods of outputdriven approach. Finally, it pointed out the important issues when output-driven EAP teaching was applied in blended learning environment. There should be enough output activities both online and in the classroom and evaluation system software should be designed to supervise and evaluate students' online learning after class.
\end{abstract}

Keywords-blended learning; EAP; output-driven approach; college English teaching

\section{INTRODUCTION}

With the development of information communications technology, some new forms of education appear in recent years. One of the most popular learning and teaching approach is the blended learning, which originated from online learning. It combines both the advantages of face-to-face traditional classroom teaching and the online learning, and is widely used in all levels of education, including elementary education, secondary education, higher education, enterprises' staff training, education training centers' teaching, etc.

Blended learning can also be used in college English teaching. Most students will learn the course of college English in their college life, and most students learn it for two years in college, which is a long period of time. However, the teaching effect of this course is not so satisfactory for both teachers and students due to many factors. Therefore, how to improve the teaching efficiency of this course becomes a hot issue for many college English teachers. This paper intends to discuss how to apply out-driven approach into the EAP teaching based on blended learning.

\section{EAP TEACHING IN UNIVERSITIES}

\section{A. Definition of EAP}

EAP is a subsidiary category of ESP, which is the counterpart of the term GE. Hutchinson and Waters were the earliest to propose the term---GE in 1987. According to

This paper was supported by the Educational Science Research Project of the Twelfth-five-year Plan in Hubei Province (Project Number: 2014B086), and the Education and Teaching Reform Project of Wuhan Textile University (Project Number: 141141007).
Hutchinson and Waters' classification, the teaching of EFL (English as a Foreign Language) can be divided into two categories: ESP---English for Specific Purposes, and GE--General English [1]. There are still two categories of ESP: the EAP---English for Academic Purposes and EOP---English for Occupational Purposes. Jordan in 1997 classified English teaching into ESP---English for Specific Purposes and EGP--English for General Purposes, and ESP can still be dividing into EAP---English for Academic Purposes and EOP---English for Occupational Purposes. EAP is further divided into ESAP--English for Specific Academic Purposes, and EGAP---English for General Academic Purposes [2]. In history, ESP was predominantly occupied by EAP especially in universities.

The above definition clearly shows the position of general English teaching and EAP teaching. The difference between the two lies in the teaching purposes instead of difficulty. General English teaching is sometimes called fundamental English teaching which offers language training for the purpose of passing an English proficiency exam, while EAP is designed for learners' academic studies.

In China, in most universities, current college English teaching is general English teaching. Students learn English from primary schools until colleges, and spend a long period and much time in their grammar and vocabulary study. The difference between the English teaching in primary schools, secondary schools, high schools and colleges lies in the difficulty. Students spend a long time in general English study, and pass a lot of English proficiency exams. But after graduation from colleges, many students still cannot use English in their working place, which is probably due to the lack of EAP teaching in the whole English teaching and learning process.

EAP teaching is a course that connects students' general English ability and their professional studies, and offers opportunities for students to use English in their academic studies and professional context.

\section{B. EAP Teaching in College English}

College English teaching has been reformed for several times, and each reform witnessed the improvement of teaching quality and students' English level. The new Guide for College English Teaching will be issued soon, in which the importance of EAP teaching will be recognized and emphasized. The EAP 
teaching is accepted in more and more universities, and becomes a hot topic in the reform of college English teaching. Although there are not many universities that conduct the EAP teaching, it will become a popular trend in the future college English teaching.

The proposal to add EAP teaching in college English teaching course system is not formed in one day, and undergoes a lot of teaching practices and researches. Although there are achievements of college English teaching reforms, but in many students' and teachers' opinion, the current college English teaching is time-consuming and inefficient. After several years' English teaching, many students still cannot speak English fluently and write properly and correctly. According to some researchers' study, college English teaching should also satisfy students' future career needs and their employers' demands. But in fact, many college graduates' English language proficiency cannot satisfy their employers' requirement.

In order to change the current college English, several scholars in the foreign language teaching field call for the EAP teaching in college English courses. Some studies showed that EAP teaching could comprehensively improve students' English language skills [3]. EAP teaching not only facilitates students' professional studies, but also improves students' learning skills and academic attainment [4]. Some universities in Shanghai have already conducted the EAP teaching according to the Referential Guidelines of College English Teaching for Universities in Shanghai. Huizhong Yang proposed in 2012 that the EAP teaching would be the mainstream of college English teaching ultimately [5].

There are still some scholars who are doubtful about EAP teaching. These scholars pointed out that there was a huge difference of students and teachers among universities in the whole country. In some key universities in Beijing and Shanghai, students' English proficiency is much better so that EAP teaching is suitable for these students. In some ordinary universities or colleges, students' English proficiency is not so good, and EAP teaching will be very difficult to be carried out in these universities. Therefore, some scholars pointed out that most students did not use English to learn their professional courses or to study abroad so that EAP teaching would not become the mainstream in the future college English teaching [6]. Some scholars made studies of the influence of EAP teaching on college students' future job, and concluded that EAP teaching had a positive influence on college graduates' job and that EAP teaching could enhance students' practical English ability and improve their working competitiveness [7].

\section{EAP Course Arrangement}

The major purpose of EAP teaching is to cultivate students' ability to use English to make oral and written communication in academic context by the training of academic listening, speaking, reading and writing. There are some similarities between EAP and EGP, both of which emphasize the training of students' listening, speaking, reading and writing. The differences between the two lie in the application context. EGP is used for every field in daily life, while EAP is used only for academic context.
It is a misunderstanding that EAP is more difficult than EGP. EAP is not EGP in a higher level, and the two are used in different contexts. EAP is to integrate English listening, speaking, reading and writing into academic learning activities, and provides the training of academic reading, academic speech, academic vocabulary, academic writing, academic note-taking, academic literature searching, etc. which are important in students' future professional English study and career. Therefore, it can be concluded that EAP is a bridge that connects EGP study and students' professional English study. It offers a link between EGP and students' professional study and future work.

The course arrangement of EAP is similar to that of EGP, but still different in the application context and purposes. The first part of EAP is still reading, but it is academic reading. According to the "higher requirements" in the Guide for College English Teaching in 2007, the reading requirements demand students to understand articles of literature review of students' professional field, to get the main idea and seize the main facts and related details. To understand the research papers and the latest development in students' major is the main purpose of academic reading, and is also very important in students' professional study, research and future work.

The second part of EAP is academic writing. The academic writing here should not only include the writing of academic papers, but also include writing of profession-related documents, such as investigation report, experiment report, legal report, business letters, etc. Academic paper writing also calls for a training of students' ability of literature searching and collecting. There are many sources to get the relevant literature in the information age. How to collect the relevant information and summarize the major points of the literature should be a skill that students must be trained of. The academic paper writing paradigm , process, format, genre features should also be introduced to the students. Other issues like the usage of punctuation, how to avoid plagiarism, how to organize the whole paper in a logic way, etc. should also be taught to the students. In the teaching of EAP writing, students' critical thinking should be trained in a systematic way.

The third part of EAP teaching is academic listening which is important to students' future study and work. The EAP listening should be focused on training students' listening comprehension of academic materials, such as academic lectures, academic presentations, etc. In the future, some students will study abroad, or work with foreign experts. In such occasions, students need to understand English lectures and probably take notes. If students have a poor listening comprehension, they can hardly understand what the professors say or the foreign experts say. Therefore, in EAP courses, listening of academic lectures, speeches, or presentations, etc. should be the training focus for the students. At the same time, note-taking skills should also be taught to the students. Only if students understand what others say can they make effective communication, so EAP listening training is the essential passage to EAP speaking training. The EAP listening and EAP speaking can be taught to the students in an integrated way.

The fourth part of EAP teaching is academic speaking. English speaking ability is an important communication skill in 
the language proficiency. Academic speaking mainly refers to making oral communication in academic context, such as making an oral academic presentation, or discussing issues related to the professional study, or making an academic speech or lecture in English, etc. These oral English trainings are conducted based on a certain academic topic or project. In the teaching practice, it can be combined with listening practice.

The fifth part of EAP teaching is the EAP translation. An EAP discourse has its unique features and needs translation skills to accurately translate the meaning. In students' future working place, translation of literature in their professional fields is greatly needed. Therefore, EAP teaching should include the translation training.

The final of EAP teaching is academic vocabulary. In any kinds of English language study, vocabulary study is usually the basic part of all the other kinds of study. The difference between EGP vocabulary and EAP vocabulary is that academic vocabulary is closely related to students' professional fields. It can be terminology, professional terms, jargons, etc.

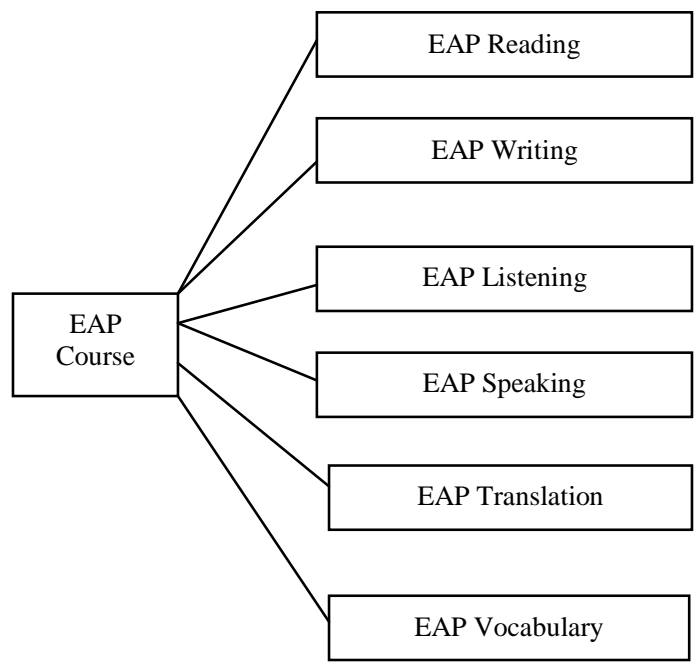

Fig. 1. EAP Course Arrangement

In Fig. 1. the major contents of EAP teaching are clearly shown. EAP teaching is still language teaching, so it also follows the common laws of language teaching. It is common for language teachers to combine the teaching of reading and writing together, and combine the teaching of listening and speaking together. Thus in EAP teaching, reading and writing can be combined together and listening and speaking can be combined together. Some scholars have already proposed an EAP teaching model that consists of two modules: One module is EAP reading and writing, and the other module is EAP oral communication [8]. In such a teaching model, the EAP oral communication is also taught with the listening skills together. In the teaching of the first module---EAP reading and writing, students' critical thinking skills should be trained, including analysis, judgment, inference, evaluation, paraphrase, selfadjustment, etc. The students' logic analysis abilities, including analysis, comparison, synthesis, abstraction, summarization, classification, etc. should be cultivated in a systematic way.

\section{OUTPUT-DRIVEN TEACHING IN BLENDED LEARNING}

\section{A. Output-driven Approach}

Professor Wen firstly proposed the "output-driven approach" in 2008 in her paper to study the teaching of the English majors in China. She concluded the features of her output-driven approach in the following three aspects: (1) output-driven hypothesis is suitable for the medium-level and high-level learners, but not suitable for the beginners or lowlevel learners; (2) output-driven hypothesis is limited to the formal foreign language teaching class; (3) output-driven hypothesis specifies that output includes not only speaking and writing, but also translation, which is different from Swain's hypothesis [9]. There are many researches on Professor Wen's Output-driven hypothesis afterwards, and many researches are made on the application of this hypothesis to non-English majors' teaching. In 2013, Professor Wen made some additional supplement to her output-driven hypothesis as follows: (1) As regards the teaching process, the driving force of output is stronger than that of input, because the output driving force can stimulate the application of language knowledge and spur students' desire to learn new language knowledge; (2) As for the teaching objective, the cultivation of students' English speaking, writing and translation can better satisfy the society's needs of talents [10].

From Professor Wen's explanation, we can see that in the output-driven approach, students' output language ability, mainly including speaking, writing and translation are highly emphasized. The output-driven approach treats these output language abilities as the stimulus to enhance students' language learning. In fact, these output language abilities are what the society needs most for a college graduate. Therefore, in the EAP teaching, output-driven approach can be applied to improve the teaching effect and students' learning motivation.

\section{B. Output-driven EAP Teaching Methods}

In an output-driven EAP teaching, the major teaching objectives should be the cultivation of students' EAP writing, speaking, and translation abilities. These language skills should be trained in a particular context so that learners can acquire them naturally and efficiently.

There are several instruction methods that can be applied in the EAP teaching. The first one is CBI---Content-based Instruction. The CBI teaching centers around the discipline knowledge, and all the teaching activities are focused on the discipline knowledge system, in which language learning and knowledge learning are combined together. In this teaching method, students learning academic English by using them in learning their professional knowledge, and this way can greatly improve students' learning motivation of English language.

Another effective instruction method is interactive teaching method, by which there are many interactive activities between students and students, and between students and teachers. By these interactions, teachers will know how well their students learn, and students can better concentrate in the classroom teaching. 
The third instruction method is project-based method. In the teaching of EAP, teachers can divide the teaching materials into several studying projects, and assign these projects to students. Students can form groups to finish these projects, which involve literature collection, academic reading, writing, listening, speaking, and translation. By finishing the projects, students can cultivate their cooperation ability, communication skills, and English language abilities. These projects can be a topic in social issues, business issues, or scientific issues, etc.

\section{Issues in Blended learning}

The teaching design of output-driven EAP teaching based on blended learning should solve the following problems: The first one is how to integrate the online learning with the classroom teaching. The second one is how to improve students' self-supervision awareness in their online-learning. Therefore, it should obey the following principles:

First, there should be enough output activities both online and in the classroom. The major goal of output-driven approach is to cultivate students' output language competence. The online learning part should offer some writing, speaking and translation exercises and tests for the students to practice their output language abilities. At the same time, teachers should arrange their classroom teaching according to students' performance online, and design some other kinds of exercises that are different from those online. The machine-human interactive software can be applied in the online speaking assignment, and the automatic evaluation software can be applied in the online writing and translation assignment. The application of the computer software can offer efficient ways of exercises and evaluation, though there may still be some mistakes in the software system.

Secondly, an online evaluation system should be established to supervise the students' online learning to ensure that they really learn after class, and such a system can offer data for teachers to design their future teaching. EAP teaching is for students with medium level or even higher level of English proficiency, so there is some difficulty for students to learn after class. If students do not learn the corresponding courses online, they obviously cannot catch up in the classroom. Thus, there should be some supervision system online to monitor students’ online learning after class.

\section{SUMMARY}

The output-driven approach is a new teaching method in foreign language teaching, and EAP teaching is the future reform trend in the college English teaching. The output-driven approach can be used in EAP teaching in many ways, such as the CBI instruction, interactive instruction, and project-based instruction. When EAP teaching is used in a blended learning environment, it can still follow the output-driven approach in all levels of the teaching activity design. The application of the output-driven approach in EAP teaching in a blended learning environment is a new and rewarding research topic which needs more in-depth studies. Future research can be made on the investigation of students' opinion of EAP teaching based on blended learning, students' learning experience of EAP teaching based on blended learning, the development of the relevant software in online learning, etc.

\section{ACKNOWLEDGMENT}

This research was supported by the Educational Science Research Project of the Twelfth-five-year Plan in Hubei Province, China ---“Research on the Teaching Models of EAP Based on Blended Learning” (Project Number: 2014B086), and the Education and Teaching Reform Project of Wuhan Textile University---"Research on the Cultivation of English Output Application Ability for Engineering University Students in Provincial Universities" (Project Number: 141141007).

\section{REFERENCES}

[1] T. Hutchinson, A. Water (eds.), English for Specific Purpose, Cambridge: Cambridge Univeristy Press, 1987.

[2] R. R. Jordan, English for Aacademic Purposes, Cambridge: Cambridge Univeristy Press, 1997.

[3] K. Hyland, English for Academic Purposes: An Advanced Resource Book, London: Routledge, 2006.

[4] B. Zou, College English teaching reform in the perspective of EAP teaching in Sino-foreign cooperative universities: An example of Xi'an Jiaotong-Liverpool University, Foreign Language World, 2015 (6): 6976.

[5] H. Yang, Some thoughts about college English teaching, Foreign Language Teaching and Research, 2012 (2): 293-297.

[6] S. Wang, C. Yao, Some thoughts on EAP teaching, Foreign Languages in China, 2013 (5): 4-10.

[7] B. Zou, B. Cao, The impact of EAP education for college graduates' occupation, TEFLE, 2016 (2): 31-36.

[8] X. Qi, The EAP course module establishment in the background of college English reform, Foreign Language World, 2015 (6): 61-68.

[9] Q. Wen, "Output-driven hypothesis and the reform of language skill courses for English majors”, Foreign Language World, No. 2, 2008, pp. 2-9.

[10] Q. Wen, "The application of output-driven hypothesis in college English teaching: thinking and suggestions”, Foreign Language World, No. 6, 2013, pp. 14-22. 